\title{
Understanding Students' C Programming Language Learning Styles: A Case Study in College of Science and Technology
}

\author{
Kezang Dema \\ Information Technology Department, College of Science and Technology, Royal University of Bhutan, \\ Chhukha, Bhutan
}

\begin{abstract}
The first year students are facing difficulties in learning C programming language when the module is being offered in their first year tenure. Ultimately, this leads to an increased failure rates in this module. On the other hand, even the faculties are having strenuous time teaching this module. The main aim of the case study is to assess and determine the different learning styles of first year students from Bachelors of engineering in Information Technology (BE1IT). And then, know the majority of the students' preferred learning style so that the faculties teaching $\mathrm{C}$ programming language are made aware about the findings. And also, recommend the faculty to redesign their pedagogical material to cater students as per their various learning styles. The VARK learning style inventory was adopted for the study which consists of 17 questionnaires. A class of BE1IT with 40 students comprising of 16 female and 24 male students were the participants. All the students were asked to take into consideration of themselves in how they learn best with the module - $\mathrm{C}$ programming language and then accordingly attempt those questionnaires and the data was collected. The study showed that majority of the students are kinaesthetic learner irrespective of the genders. The faculty teaching the first year students need to understand that this method may be helpful in helping the students learn better. The pedagogical materials used to teach them may be one of the factor which is not helping them to learn better as it is not correlating with their learning styles. After having known the different type of learners, the faculty were made aware of the findings and were recommended to re-design their pedagogy and andragogy materials accordingly to cater all the students' learning. Keywords: Learning styles, C programming language, VARK learning style model, Kinaesthetic
\end{abstract}

DOI: $10.7176 / J I E A / 11-1-02$

Publication date: January $31^{\text {st }} 2021$

\section{Introduction}

Programming courses are very important components of the curriculum to be studied especially in the field of Information Technology, science, mathematics and Engineering (Rosminah, Derus \& Ali, 2012). In College of Science and Technology (CST), C programming language is being offered to all the first year students irrespective of their varying programme. As said by Gomes, Anabela and Mendes (2007), the programming courses are often found to be problematic and students are facing difficult time learning it, thus showing higher failure rates. Further supported by Rosminah, Derus \& Ali (2012), programming courses are considered to be very difficult and complex subject whereby the students are facing difficulties in learning those courses. Even in CST, the first year students are finding the programming module very complex and difficult to learn leading to higher failure rate compared to other modules.

Among many, one of the effective strategy that can help students learn better with this module could be by understanding their learning style and then accordingly designing the pedagogical materials. Because some studies found out that the learning styles indeed affect a student's ability to learn (Maia, Serey \& Figuieredo, 2017). There could be a better ways to teach the $\mathrm{C}$ programming language if a tutor know their students' learning styles. So this require scrupulous study to know the students' learning styles and then take up the responsibility to design the pedagogical materials with which they can teach in a way that makes them understand better. A study by Thomas and his team (2002), found out that some student's learning styles are more suited to learning programming than others, so there is a need to do the assessment and know the BE1IT students' learning style that best suits to learn $\mathrm{C}$ programing language module.

Learning style is one of the popular concept in areas like psychology and education especially intended to identify how people learn best (Cherry, 2019). Fleming (2001) defines learning style as an individual's characteristics and preferred ways of gathering, organizing, and thinking about information. The learning style for different individual varies according to their preference with which they are able to capture, process and understand the information easily (Maia, Serey \& Figuieredo, 2017). Many learners are assumed to have different learning styles that makes them to learn better. Many researchers, authors, educationists, psychologists have come up with different models of learning styles like the Carl Jung's Theory, Albert Bandura's Theory, David Kolb's learning style, VAK/VARK models and many more (Alqunayeer \& Zamir, 2015). There are many types of learning styles like verbal, aural, visual, kinaesthetic, social, solitary, logical and many more. Those learning styles basically group common ways that people learn. In order to know the varying learning styles, the study needs to adopt one particular model. 
Among all, the VAK model is one of the most popular learning styles which was developed by psychologists in the 1920's. According to this model, the learner prefer to learn in one of the three ways: visual, auditory or kinaesthetic. A variation on the acronym with the addition of one more learning preference known as reading/writing was later formed by New Zealand-based teacher called Neil D. Fleming known as VARK learning style (Othman \& Amiruddhin, 2010). The VARK model of learning styles explains that there are four main types of learners. These different types of learners are identified by knowing whether they have a preference for visual learning, auditory learning, reading and writing or kinaesthetic learning (Cherry, 2019). Based on their learning preferences, those learners are categorized under the four types: a) Visual learners, (b) Auditory learners, (c) Reading/writing learners and (d) Kinaesthetic learners. This study is going to adopt this VARK learning style model.

As per the VARK learning style model, the visual learners are those who prefer learning by seeing and usually absorbs and retains information better when it is presented in the form of pictures, diagrams, charts, illustrations, hand-outs, videos (Othman \& Amiruddhin, 2010). The auditory-dominant learner prefers listening to what is being presented and they usually learn best by hearing information i.e the reinforcement made by sound (Cherry, 2019). The reading-or-writing-dominant learners strongly prefer text-based learning materials, reading articles on the internet, writing in diaries, looking up words in the dictionary and searching the internet for just about everything (Elrick, 2018). The kinaesthetic learners are also known as tactile learners and they learn better by doing or having a physical "hands-on" experience (Cherry, 2019).

In this work, firstly the best learning style questionnaire or inventory will be selected and then, it will be distributed to all the students to respond to the questionnaires. Since the main focus will be more in knowing the Visual, Aural, Read/Write and Kinaesthetic (VARK), the learning style questionnaires used will be based on the Neil Fleming's VARK questionnaires. These questionnaires will help in knowing the students learning styles. The data collected will be used for further analysis and the result obtained will obviously result in knowing the different learning styles of a student and thus, it may help the faculty in knowing the predominant learning styles of the students and then accordingly, re-designing the pedagogical materials of $\mathrm{C}$ programming language course in much effective manner which ultimately will help students learn more and get better results.

Hypothesis: Majority of the students will be kinaesthetic learners as the $\mathrm{C}$ programming language is to learn more by hands-on practice executed practically.

\section{Literature Review}

The term 'learning styles' in a simple word refers to a group of different mode or method that a person uses to learn, collect, process and understand the information (Maia, Serey and Figueiredo, 2017). Different authors may have different definition for it, like for instance Parshler et al. (2009) defines learning style as the concept that individuals differ in regard to what mode of instruction or study is most effective for them. According to Willingham, Hughes \& Dobolyi (2015), every individual differs in how they learn. As a learner, it is very much important that understand and recognize our own learning style that best suits us, so that it helps in improving the speed and quality of ones' learning. And also, as a faculty, it is outmost important that one take time to understand the best learning styles that best suits majority of the students and adopt it for their easy learning (Pritchard, 2014). A study done by Shaw (2012) used the Kolb's learning style inventory in order to determine the most prominent learning style of 144 students who are studying ASP.NET programming language course. The study was also intended to determine the relationship among the learning styles, participation type and learning performance for programming language. The study showed that majority of the students were accommodator' learners as per the Kolb's learning style model. Similarly, Seyal et al. (2015) used the Kolb's learning style inventory to understand the student's learning styles especially by considering the first year students pursuing the Bachelor of Internet computing degree program. In their study, it was found out that the converging and assimilating learning styles are significant among the students which was further validated with the associated that it had with their pass or credit grade. This further led them to provide some recommendations to enhance and enrich the teaching learning process especially in programming courses.

Aualkernan, Allert and Qadah (2006), in their study tried to find the relationship between the learning styles of the computer science and engineering students based on their cultural differences. The result based on the comparative data on students' learning style and their course outcomes showed that there is a strong similarities between the learning styles among the students despite their cultural differences. This shows that the cultural differences are not going to make any differences especially in students' learning style, so this can help in creating an effective teaching materials that can be applied globally.

Maia, Serey and Figueiredo (2017) performed a systematic review by collecting 21 relevant papers related to learning styles in students and how it affect especially in teaching the programming course. The findings showed that Solomon-Felder which is another learning style model is the most used model. Most importantly, the result indicated that the different learning styles of the students indeed affect the students' ability to learn. In this case, it's in the hand of the faculty to understand their student's different learning styles and then accordingly design 
and develop their pedagogical material as per the majority's learning styles so that it caters to their learning. Seyal, Noah \& Rahman (2015) found out that majority of the students out of 120 participants are kinaesthetic learners when it comes to e-learning management system ("Ask-n-Learn") platform. The study used the VARK questionnaire and this too showed that there is a relationship between the students' learning styles and how much they learn based on their learning style preferences.

In order to help all the different types of learners, there is a need to understand and know the various learning styles. Based on the emergence of various learning styles, there came the evolution of models whereby each learning style model adopts different theories and strategies. One of the research conducted by Coffield et al. (2004), says that there are about 71 different learning style models proposed by various authors as per their research and work. But, the fact is, not all types of learning style models are being accepted and used. Only few such as the VAK/VARK model, Dunn and Price models, David Kolb's model and Honey and Mumford's model are widely being accepted and used (Coffield et al., 2004).

\section{Methodology}

Among many, especially in the field of teaching and learning, it is of outmost important for both the faculty and students to understand about the learning styles. Every individual will have different way to learning style in order to acquire knowledge (Willingham, Hughes \& Dobolyi, 2015). For some, they learn more through images, maps, and many more, and for some through hearing the spoken words, some through reading and writing and some through doing practically. Some interesting fact seen is also that some people possess more than one learning styles depending upon the situation and preferences.

In a class, there could be many student with varying learning style and intelligence. As a faculty, it is very important for oneself to know your students' learning styles. In order to know the fact, it is the responsibility of the teacher to assess the learning styles of their students and accordingly adapt the classroom teaching methods to best fit the student's learning style (Pritchard, 2014). This section will contain the details about the data collection from the students with the class size of 40 . The data collected will be analyzed further to know about students' different learning styles. The methodology used for the study is an online survey based on VARK learning style inventory and the procedures followed are as given below and in Figure 1.

1. Selection of the best learning style inventory

2. Data collection from the students: Making the students to participate and know their own learning style using the selected VARK learning style inventory

3. Data analysis and interpretation

4. Result and conclusion

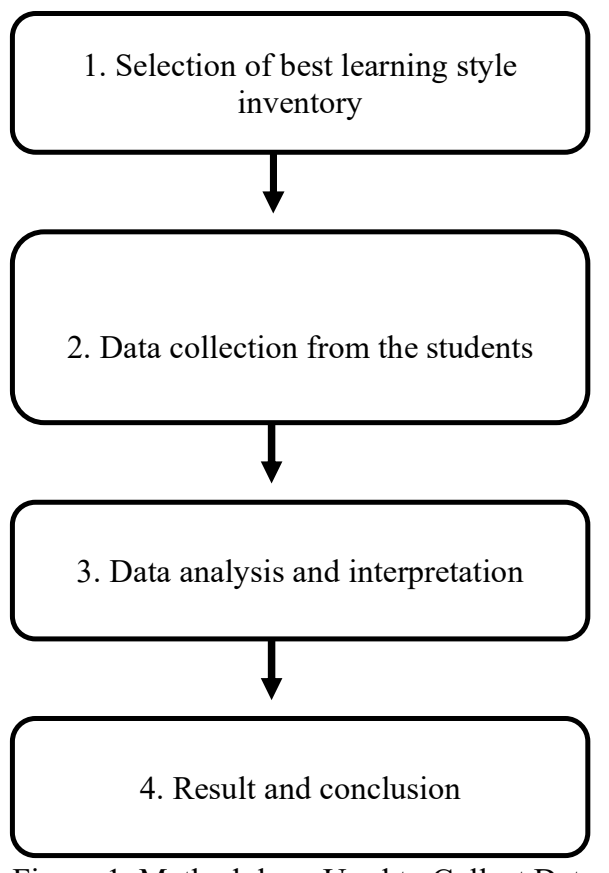

Figure 1. Methodology Used to Collect Data

Among many different learning style models, the VARK learning style model has been selected and adopted to assess the most prominent learning style that majority of the student possess to learn so that it gives an idea to adopt the best teaching pedagogy that best correlate with the students' learning style. The VARK stands for Visual, 
Aural, Read/Write and Kinesthetic sensory modalities that are used for leaning information and it is one of the highly reputed and mostly used model especially by the teachers and educators. There are many VARK learning style questionnaires online that can be used to know about one's learning style. Among them, Neil Fleming's VAK/VARK learning style questionnaire was being selected for the assessment (VARK, 2019).

To collect the data, all 40 students were made to sit in the laboratory and were given the link to access those questionnaires and know their own learning styles. The type of their learning style based on their report generated from the survey were collected and recorded for further analysis and interpretation as formulated in the tabular form given in Table 1.

Table 1. Survey data collection

\begin{tabular}{|c|c|c|c|}
\hline SI. NO & Student Number & Gender & Learning style \\
\hline 1. & STD1 & Male & Kinesthetic \\
\hline 2. & STD2 & Male & Kinesthetic \\
\hline 3. & STD3 & Male & Kinesthetic \\
\hline 4. & STD4 & Male & Kinesthetic \\
\hline 5. & STD5 & Female & Kinesthetic \\
\hline 6. & STD6 & Male & Aural \\
\hline 7. & STD7 & Female & Visual \\
\hline 8. & STD8 & Female & Kinesthetic \\
\hline 9. & STD9 & Male & Aural \\
\hline 10. & STD10 & Female & Visual \\
\hline 11. & STD11 & Male & Kinesthetic \\
\hline 12. & STD12 & Male & Kinesthetic \\
\hline 13. & STD13 & Male & Aural \\
\hline 14. & STD14 & Female & Kinesthetic \\
\hline 15. & STD15 & Male & Visual \\
\hline 16. & STD16 & Male & Kinesthetic \\
\hline 17. & STD17 & Female & Aural \\
\hline 18. & STD18 & Male & Kinesthetic \\
\hline 19. & STD19 & Male & Visual \\
\hline 20. & STD20 & Male & Aural \\
\hline 21. & STD21 & Male & Read/Write \\
\hline 22. & STD22 & Female & Kinesthetic \\
\hline 23. & STD23 & Male & Visual \\
\hline 24. & STD24 & Male & Aural \\
\hline 25. & STD25 & Female & Kinesthetic \\
\hline 26. & STD26 & Female & Aural \\
\hline 27. & STD27 & Male & Kinesthetic \\
\hline 28. & STD28 & Male & Visual \\
\hline 29. & STD29 & Female & Kinesthetic \\
\hline 30. & STD30 & Male & Aural \\
\hline 31. & STD31 & Male & Read/Write \\
\hline 32. & STD32 & Female & Read//write \\
\hline 33. & STD33 & Male & Visual \\
\hline 34. & STD34 & Female & Aural \\
\hline 35. & STD35 & Female & Read/Write \\
\hline 36. & STD36 & Female & Kinesthetic \\
\hline 37. & STD37 & Female & Read/Write \\
\hline 38. & STD38 & Male & Kinesthetic \\
\hline 39. & STD39 & Male & Aural \\
\hline 40. & STD40 & Female & Kinesthetic \\
\hline
\end{tabular}

The data collected were further interpreted and analyzed to determine the different type of learning style preferences as per the gender difference. Also, the analysis was perform for overall students irrespective of the genders. The various interpretation and analysis will be represented and explained in results and discussion section. Finally, the results and conclusion obtained from the analysis is presented.

\section{Results and Discussion}

All the first year students from BE1IT were selected for the study. The class had a total of 40 students with the 
combination of 16 female students and 24 male students as depicted in Table 2 and Figure 2.

Table 2. Total number of respondents

\begin{tabular}{|c|l|l|}
\hline \multicolumn{3}{|c|}{ Total Number of Respondents } \\
\hline SI. NO & Gender & Total \\
\hline 1. & Female & 16 \\
\hline 2. & Male & 24 \\
\hline
\end{tabular}

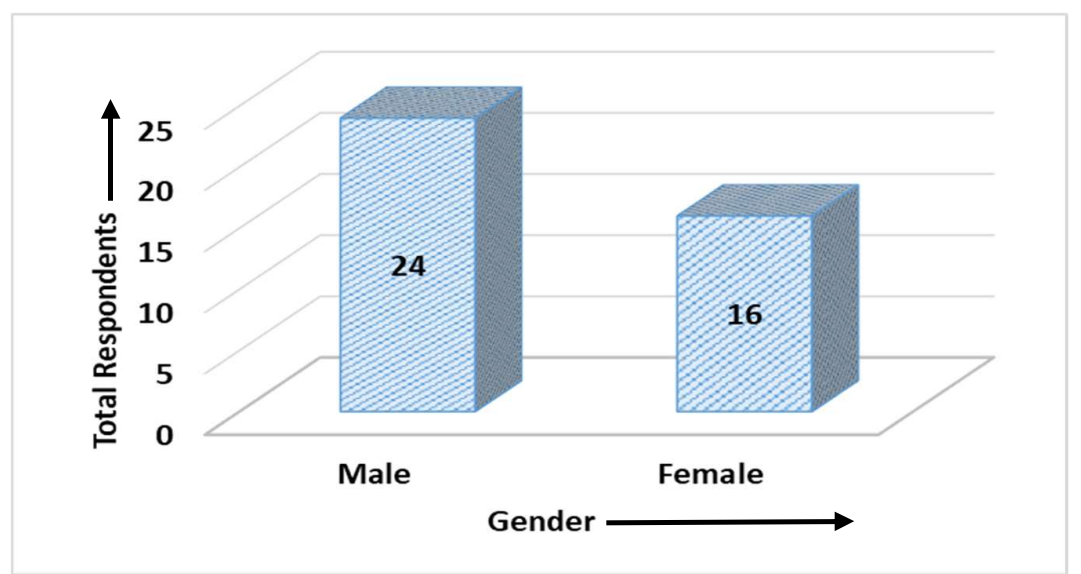

Figure 2. Total Number of Respondents

The different learning styles of 16 female students were evaluated using the same VARK questionnaires. The results obtained is shown in Table 3 in terms of numbers wherein the leading number is 8 kinesthetic learners who learns by doing it practically (hands-on). A total of 3 female students are of learners who understand and learn more with aural mostly to do with listening to lectures. Again, 3 of them learn better by reading and writing. Lastly, 2 of them are visual learners who learn more with the visual presentations like graphs and diagrams. The findings are also shown in Figure 3 in term of percentage calculation: 50\% of the female learners are kinesthetic learners, $19 \%$ each are aural learners and $19 \%$ are read/write learners and $12 \%$ of them are visual learners. Majority of the female learners falls under kinesthetic learner category. This helps in knowing that the students can learn $\mathrm{C}$ programming in best way if the faculty is going to teach them with the inclusion of more kinesthetic methods in their teachings by providing them to do the work more practically and physically instead of making them to just sit and listen to the teachings.

Table 3. Different learning styles in female students

\begin{tabular}{|c|l|l|}
\hline \multicolumn{3}{|c|}{ Learning Styles in Female Students } \\
\hline Sl. No. & Learning Styles & Total \\
\hline 1. & Visual & 2 \\
\hline 2. & Aural & 3 \\
\hline 3. & Read/Write & 3 \\
\hline 4. & Kinesthetic & 8 \\
\hline
\end{tabular}

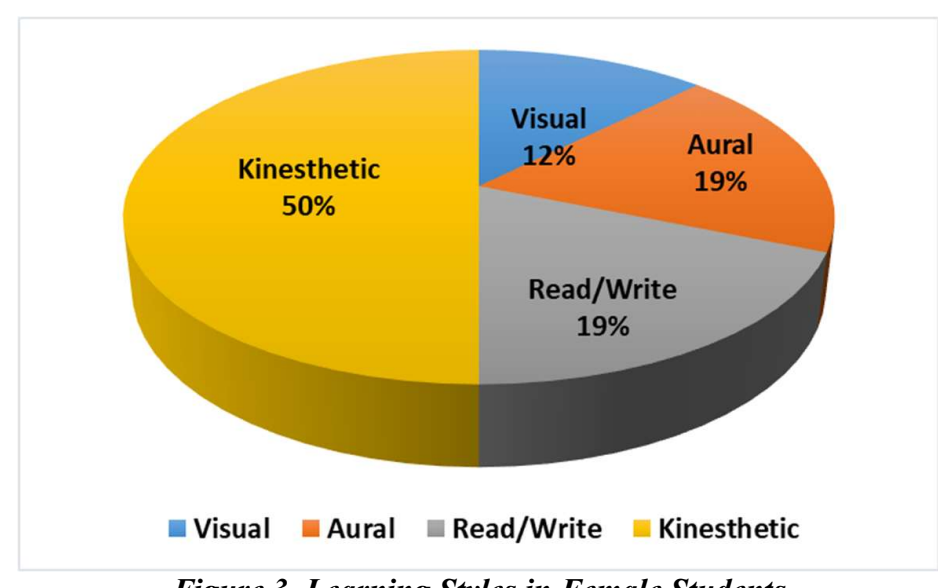

Figure 3. Learning Styles in Female Students 
Similarly, the evaluation of the different type of learning styles preferences adopted by male students were carried out and the results are shown in Table 4 and Figure 4. A study consisted of a total of 24 male students, among which the categorization showed maximum number in kinesthetic style followed by aural, visual and $\mathrm{read} /$ write style. 10 students are kinesthetic learners, 7 learn more by aural, 5 learn more by visual and 2 by reading and writing. The division in terms of percentage is shown in Figure 4 which shows that $42 \%$ of them are kinesthetic learner, $29 \%$ are aural learner wherein they learn best by hearing it, $21 \%$ are visual learners who learn best by seeing it with the diagrams, flowcharts, drawings, graphs, many more and $8 \%$ learns better by reading and writing. In the category of male students too, it can be seen that majority of them are kinesthetic learners as observed in female students category. This further helps in knowing that majority of the students learns more by doing it practically by themselves with hands-on irrespective of the gender as both the categorization has the kinesthetic learner as the leading learning style.

Table 4. Different learning styles in male students

\begin{tabular}{|c|l|l|}
\hline \multicolumn{3}{|c|}{ Learning Styles in Male Students } \\
\hline Sl. No. & Learning Styles & Total \\
\hline 1. & Visual & 5 \\
\hline 2. & Aural & 7 \\
\hline 3. & Read/Write & 2 \\
\hline 4. & Kinesthetic & 10 \\
\hline
\end{tabular}

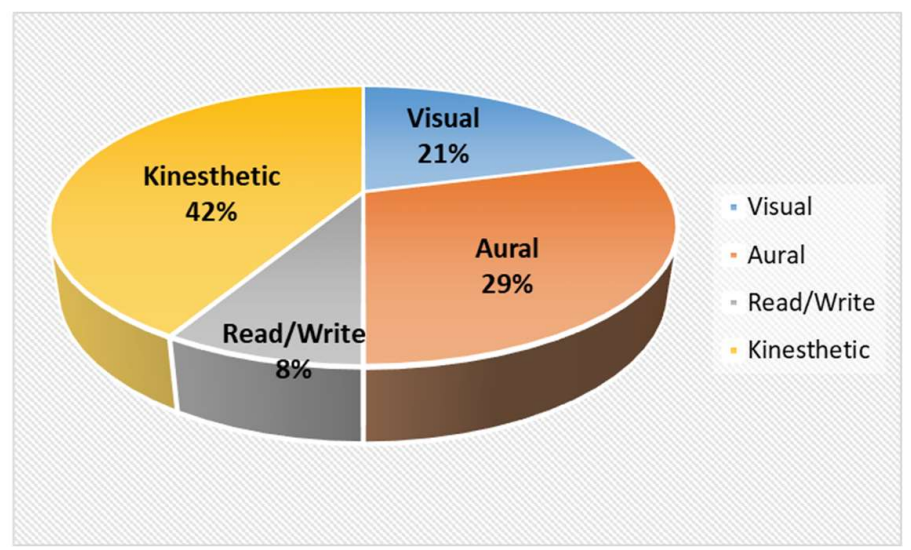

Figure 4. Learning Styles in Male Students

As already discussed, the third category is going to show the results obtained for all 40 students without further division based on genders. As reflected clearly in the Table 5, 18 of them are kinesthetic learner, 10 of them are aural learner, 7 of them are visual learner and lastly, 5 of them learn more and easily by reading and writing.

Table 5. Different learning styles in all students

\begin{tabular}{|c|l|l|}
\hline \multicolumn{3}{|c|}{ Learning Styles of Students } \\
\hline Sl. No. & Learning Styles & Total \\
\hline 1. & Visual & 7 \\
\hline 2. & Aural & 10 \\
\hline 3. & Read/Write & 5 \\
\hline 4. & Kinesthetic & 18 \\
\hline
\end{tabular}




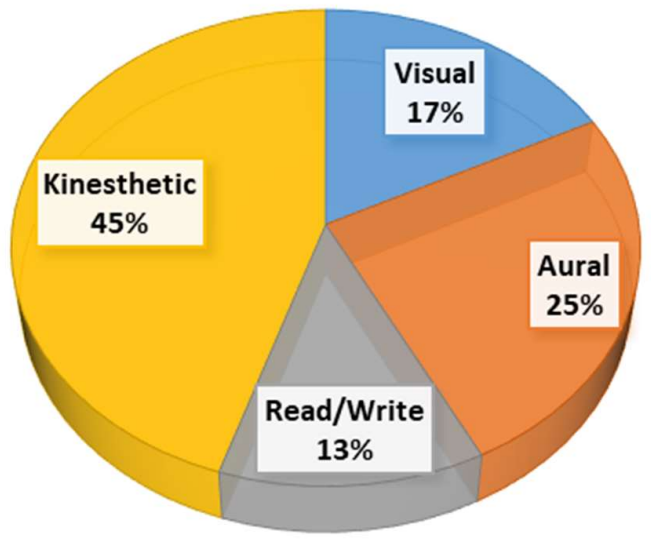

Figure 5. Learning Styles in All Students

The same result can be represented in terms of percentage value as shown in Figure 5. The figure shows that the kinesthetic learners of BE1IT covers $45 \%$, followed by $25 \%$ of them falling under aural category, $17 \%$ of them under visual learners and $13 \%$ of them under read/write learning style. The findings show that majority of the students are those learners who learn best by doing the task practically and physically. In reference to Table no. 3 and Figure no. 3, the result was based on only selected girls' preference. The result yielded the leading category with $50 \%$ which represented the kinesthetic mode of learning style. Also, in Figure 4 and Table no 4 , the analysis on male category showed that in here too, majority of the boys i.e., $43 \%$ of them learn through kinesthetic learning style. The evaluation done together for both the genders as shown in Figure 5 and Table 5 showed that overall, majority of the students have the kinesthetic way of learning style.

The result acquired hence proved the stated hypothesis. Based on the above mentioned survey, the faculty needs to understand that majority of the student are kinesthetic learners who learn by doing it practically, who implement it practically and physically. Additional activity that needs to be included to cater this type of students are: a) Allowing students to move around and interact, b) Making students to write on the whiteboard, c) Letting them apply more of practical with their own hands, d) Letting them experience practically, e) Hands-on-experience and f) Being part of a team and have discussion and demonstration. Having focus on this type, the faculty also need to cater others with other learning styles as well.

\section{Conclusion}

The first year students from BE1IT in CST is facing difficulties in learning the C programming language module offered in first year when they join the college for the first time. The faculties teaching that particular module is also having equivalent difficulties in teaching the first year students and mostly get to see an average result at the end of the semester with higher failure rates as compared to other modules. As a way to help the students learn better in this module, it's the duty of a faculty to understand their students' learning styles and according prepare their pedagogical materials which will help them learn better because many studies showed that the learning styles do affect the students' learning. The study matched with the hypothesis made whereby majority of the student are kinesthetic learners and this will include those students who prefer to learn by doing it practically. And of course, the $\mathrm{C}$ programming language is a kind of module that normally are learned better by majority with more of practice and doing it hands-on practically.

The study showed that there are more of kinesthetic learners in the class. Based on the results obtained from the study, a specific recommendations were provided to the faculty teaching the particular module for improvising and re-design their pedagogy and andragogy design of the $\mathrm{C}$ programming module. Although the majority are kinesthetic learners, there are few who prefer different learning styles, so it completely lies in the hand of the faculty teaching them to again design their pedagogical teaching materials that will cater to other remaining students as well and help them learn better. The future study could cover the in-depth study of the students' learning style by including all first year students of various other programmes. And also, the future study could include the study of a relationship between their learning styles and their grades which will help in determining the impact of their learning styles on their performance.

\section{References}

Alqunayeer, H.S., \& Zamir, S. (2015). Identifying learning styles in EFL classroom. International Journal of Learning and Teaching, 1, 82-87.

Cherry, D. (2019). Overview of VARK learning styles. [Online] Available: https://www.verywellmind.com/varklearning-styles-2795156 
Coffield, F., Moseley, D., Hall, E., \& Ecclestone, K. (2004). Learning styles and pedagogy in post-16 learning: a systematic and critical review (PDF). London: Learning and Skills Research Centre

Elrick, L. (2018). 4 types of learning styles: how to accommodate a diverse group of students. [Online] Available: https://www.rasmussen.edu/degrees/education/blog/types-of-learning-styles/

Gomes, A., \& Mendes, A.J. (2007). Learning to program - difficulties and solutions. International Conference on Engineering Education-ICEE2007.

Maia, M., Serey, D., \& Figuieredo, J. (2017). Learning styles in programming education. IEEE Frontiers in Education Conference (FIE)

Othman, N., \& Amiruddin, M.H. (2010). Different perspectives of learning styles from VARK Model. International conference on learner Diversity

Pritchard, A. (2014). Learning styles -Ways of learning: learning theories and learning styles in the classroom. (3rd ed.). New York: Routledge, pp. 46-65.

Rosminah, S., Derus, S.R.M., \& Ali, A.Z.M. (2012). Difficulties in learning programming: Views of students. 1st International Conference of Current Issues in Education, ICCIE2012., Yogyakarta, Indonesia.

Seyal, A.H., Noah, M., \& Rahman, A. (2015). Understanding learning styles, attitudes and intentions in using elearning system: Evidence from Brunei. World Journal of Education, 5(3), 61-72

Seyal, A.H. et al. (2015). Understanding students learning style and their performance in computer programming course: Evidence from bruneian technical institution of higher learning. International Journal of Computer Theory and Engineering, 7(3), 241-247

Shaw, Ruey-Shiang. (2012). A study of the relationships among learning styles, participation types, and performance in programming language learning supported by online forums. Computers and Education (Elsevier). 58(1), 111-120

Thomas, L., Ratcliffe, M., Woodbury, J., \& Jarman, E. (2002). Learning styles and performance in an introductory programming sequence. Proceedings of the 33rd SIGCSE Technical Symposium on Computer Science Education

VARK. (2019). The VARK questionnaire. [Online] Available: http://vark-learn.com/the-vark-questionnaire/

Willingham, D. T., Hughes, E. M., \& Dobolyi, D. G. (2015). The Scientific Status of Learning Styles Theories. Teaching of Psychology. 42 (3), 266-271. doi:10.1177/0098628315589505, https://doi.org/10.1177/0098628315589505

Zualkernan, I.A., Allert, J., \& Qadah, G. (2006). Learning Styles of Computer Programming Students: A Middle Eastern and American Comparison. IEEE Transactions on Education. 49(4), 443-450. Doi: 10.1109/TE.2006.882366 